Título del artículo

SYNTHESIS OF CHIRAL CARBOSILANE DENDRIMERS WITH L-CYSTEINE AND NACETYL-L-CYSTEINE ON THEIR SURFACE AND THEIR APPLICATION AS CHIRAL SELECTORS FOR ENANTIOMER SEPARATION BY CAPILLARY ELECTROPHORESIS

Autores

Sara Quintana, María Ángeles García, María Luisa Marina, Rafael Gómez, F. Javier de la Mata, Paula Ortega.

Revista, año, volumen, número, páginas

Tetrahedron: Asymmetry Volume 28, Issue 12, 15 December 2017, Pages 1797-1802

Available at https://doi.org/10.1016/j.tetasy.2017.10.028

Elservier () Editorial

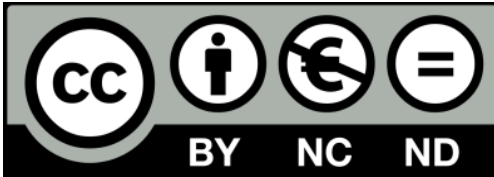

This work is licensed under a Creative Commons Attribution-NonCommercialNoDerivatives 4.0 International License. 
Manuscript submitted to Tetrahedron: Asymmetry

Corresponding Author: Dra. Paula Ortega

Departamento de Química Orgánica y Química Inorgánica

Universidad de Alcalá-CIBER-BBN

Campus Universitario. Edificio de Farmacia

28871 Alcalá de Henares. Spain.

Tel: (+34) 91 8854679. Fax: (+34) 918854683.

E-mail: paula.ortega@uah.es

\title{
SYNTHESIS OF CHIRAL CARBOSILANE DENDRIMERS WITH L- CYSTEINE AND N-ACETYL-L-CYSTEINE ON THEIR SURFACE AND THEIR APPLICATION AS CHIRAL SELECTORS FOR ENANTIOMER SEPARATION BY CAPILLARY ELECTROPHORESIS
}

\section{Sara Quintana, ${ }^{\mathrm{a}}$ María Ángeles García, ${ }^{\mathrm{c}}$ María Luisa Marina, ${ }^{\mathrm{c}}$ Rafael Gómez, ${ }^{\mathrm{a}, \mathrm{b}}$ F. Javier de la Mata, ${ }^{\mathrm{a}, \mathrm{b} *}$ Paula Ortega ${ }^{\mathrm{a}, \mathrm{b} *}$}

aDepartamento de Química Orgánica y Química Inorgánica, Universidad de Alcalá, Campus Universitario, E-28871 Alcalá de Henares, Spain. E-mail: javier.delamata@uah.es. Fax: +34 91 8854683

${ }^{\mathrm{b}}$ Networking Research Center on Bioengineering, Biomaterials and Nanomedicine (CIBERBBN), Spain.E-mail: paula.ortega@uah.es.

Fax: +34918854683

'Departamento de Química Analítica, Química Física e Ingeniería Química, Universidad de Alcalá, Campus Universitario, E-28871 Alcalá de Henares, Spain. E-mail: mluisa.marina@uah.es.

\begin{abstract}
The synthesis of chiral carbosilane dendrimers functionalized with cysteine and $\mathrm{N}$ acetylcysteine groups is presented in this work. These dendrimers were obtained through thiol-ene addition reactions and their application as chiral selectors in Capillary Electrophoresis was investigated. Four drugs used as model compounds were analyzed under different experimental conditions observing that the use of a first generation dendrimer containing 4 terminal N-Acetyl-L-cysteine groups enabled the enantiomeric
\end{abstract}


discrimination of razoxane being this discrimination power similar to that obtained with other powerful chiral selectors such as cyclodextrins.

KEYWORDS: carbosilane, dendrimers, chiral, electrophoresis

\section{INTRODUCTION}

The separation and determination of the enantiomers of chiral drugs is an important issue in the pharmaceutical analysis because one of the enantiomers may be pharmacologically active while the other(s) may have a different biological activity, can be inactive or in the worst case be toxic. 1-3 In the last years, an important number of drugs are developed as single isomers instead of racemic active ingredients. In this sense, the increasing use of drugs marketed as pure enantiomers requires powerful enantioselective synthesis methods and potent and sensitive analytical techniques to control enantiomeric impurities. The best form to obtain only one enantiomer would be to prepare it following an enantioselective synthesis, but frequently this route is very complicated, rarely practical, and almost always expensive. A variety of analytical techniques such as gas chromatography (GC), HPLC, supercritical fluid chromatography (SFC), and capillary electrophoresis (CE) have been used to obtain optically active compounds in analytical or preparative scale. ${ }^{4-6}$ Chiral CE has proven to be one of the most relevant analytical techniques used for the direct chiral separation and determination of the enantiomers of chiral compounds due to its inherent advantages such as simplicity, high efficiency and resolution power, rapid analysis and a reasonable operating cost. Most chiral separations by $\mathrm{CE}$ are carried out by using Electrokinetic Chromatography (EKC), that is characterized by the addition of chiral selector/s (CSs) to the separation buffer formed the so called background electrolyte (BGE). The CS forms a complex with both enantiomers, giving rise to differences in the electrophoretic mobility depending on the type of interactions between the CS and the chiral compound. Many compounds with chiral centers have been used as CSs such as cyclodextrins and their derivatives, ${ }^{6}$ polysaccharides, ${ }^{7}$ antibiotics, ${ }^{8}$ surfactants, ${ }^{9}$ ionic liquids, ${ }^{10}$ and dendrimers, ${ }^{11,12}$ among others. Dendrimers are highly branched macromolecules of low polydispersity. The use of dendrimers have been shown in important different biomedical applications ${ }^{13}$ and also in the analytical field, for separation of proteins, ${ }^{14-18}$ amino acids, ${ }^{19}$ isomers of neutral phenol molecules ${ }^{20}$ and aromatic compounds. $^{21}$

The chirality in dendritic systems could be achieved by different ways: i) the presence of sterogenic centers in the dendrimer core, ${ }^{22}$ ii) the presence of stereogenic centers on the branches ${ }^{23}$ and iii) introducing chiral molecules attached to the dendrimer surface, ${ }^{24}$ as a result of their controlled synthesis and unique properties. In our knowledge, only one example of the use of carbosilane dendrimers modificated with $\beta$-cyclodextrins as chiral stationary phases have been 
evaluated in capillary electrochromatography (CEC) of separation the enantiomers of chlortrimeton, promethazine, and benzedrine. ${ }^{25}$

In this paper, the synthesis of two families of chiral carbosilane dendrimers through their functionalization with the L-enantiomers of Cysteine and N-Acetyl-L-cysteine on their surface are presents. These dendrimers containing multiple chiral units have been tested as new chiral selectors, to separate the enantiomers of a group of four chiral drugs with different pharmaceutical activity and pKas values as model compounds.

\section{RESULTS AND DISCUSSION}

Chiral carbosilane dendrimers have been obtained through the inclusion of chiral centers on the dendritic surface. To achieve this goal we have selected two enantiomerically pure molecules as L-Cysteine and N-Acetyl-L-cysteine. The reason for this election is that in addition to the presence of a chiral center these two molecules contain a thiol group (-SH) that can be used for the functionalization of the dendritic periphery through well-know thiol-ene addition reactions to dendrimers with terminal olefin functionalities as we have previously described. ${ }^{26-28}$

The reaction of these two cysteine derivatives with carbosilane dendrimers presenting terminal vinyl groups, $\mathrm{G}_{\mathrm{n}} \mathrm{SiV}_{\mathrm{m}}(\mathrm{n}=0, \mathrm{~m}=4 ; \mathrm{n}=1, \mathrm{~m}=8$ and $\mathrm{n}=2, \mathrm{~m}=16$ ), leads to the hydrothiolation reaction of these dendrimers using a little excess of the thiol derivative under UV irradiation ( $365 \mathrm{~nm}$ ) and with the presence of the radical initiator 2,2-dimethoxy-2-diphenylacetophenone (DMPA) in 5\% molar ratio with respect to thiol groups. After ca. $6 \mathrm{~h}$. the chiral carbosilane dendrimers $\mathrm{G}_{\mathrm{n}} \mathrm{Si}\left(\mathrm{SCH}_{2} \mathrm{CH}\left(\mathrm{NHCOCH}_{3}\right)(\mathrm{COOH})\right)_{\mathrm{m}}(\mathrm{n}=0, \mathrm{~m}=4(\mathbf{1}) ; \mathrm{n}=1, \mathrm{~m}=8$ (2) and $\mathrm{n}=2, \mathrm{~m}=16(3))$ and $\mathrm{G}_{\mathrm{n}} \mathrm{Si}\left(\mathrm{SCH}_{2} \mathrm{CH}\left(\mathrm{N}^{+} \mathrm{H}_{3}\right)(\mathrm{COOH}) \mathrm{Cl}^{-}\right)_{\mathrm{m}}(\mathrm{n}=0, \mathrm{~m}=4(4)$ and $\mathrm{n}=1, \mathrm{~m}=8(\mathbf{5}))$ were obtained (Scheme 1). After purification by size exclusion chromatography, dendrimers 1-3 were isolated as a white solid in moderate yields, soluble in polar solvents as alcohols and DMSO but insoluble in water.

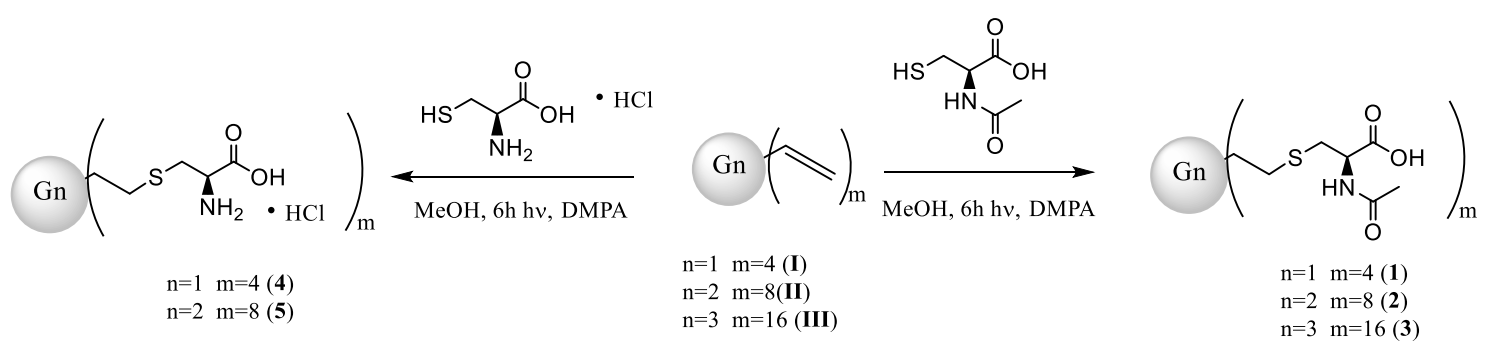

-Scheme 1. Synthetic pathway for dendrimers 1-3

The inclusion of the acetyl cysteine fragment on the dendritic surface was confirmed by ${ }^{1} \mathrm{H}$ NMR spectroscopy by means of the disappearance of the signal corresponding to vinyl groups and the presence of two new signals at ca.2.60-2.65 ppm attributed to the sulfur-bonded methylene group close to silicon atom, indicating that the reaction was complete. In the case of cysteine derivatives, 
the ${ }^{1} \mathrm{H}$ NMR spectra showed the presence of small amounts of vinyl groups after the thiol-ene reaction, despite the excess of cysteine used, indicating that the reaction was not complete. The percentage of vinyl groups unreacted increased with the dendrimer generation $(\mathrm{G} 0 \cong 5 \%$ and

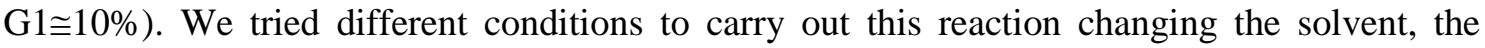
temperature, the ratio between reactants, etc., but in all cases the reaction did not reach completion indicating that in some molecules not all terminal groups suffer functionalization.

The structural characterization of compounds 1-5 was carried out by NMR spectroscopy and elemental analysis. Figure 1 shows the proposed structures for two of these derivatives.

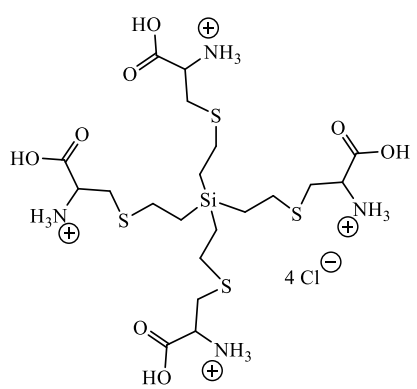

$\mathrm{G}_{0} \mathrm{Si}\left(\mathrm{SCH}_{2} \mathrm{CH}\left(\mathrm{N}^{+} \mathrm{H}_{3}\right)(\mathrm{COOH}) \mathrm{Cl}^{-}\right)_{4}$

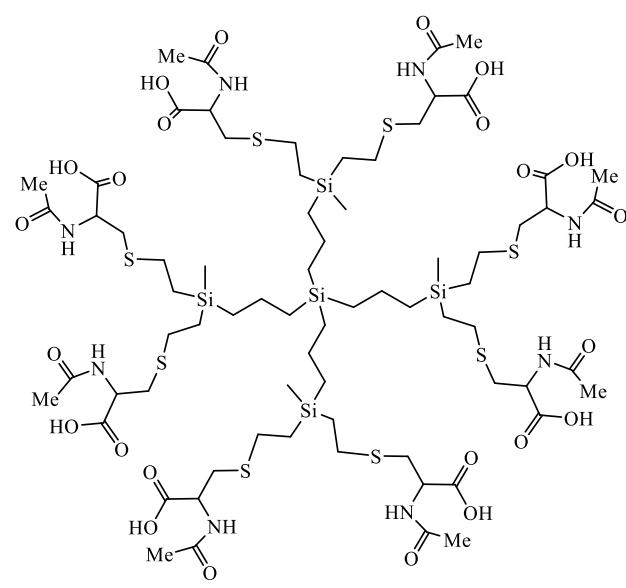

$\mathrm{G}_{1} \mathrm{Si}\left(\mathrm{SCH}_{2} \mathrm{CH}\left(\mathrm{NHCOCH}_{3}\right)(\mathrm{COOH})\right)_{8}$ (2)

Figure 1. Proposed structures for dendrimers $\mathrm{G}_{0} \mathrm{Si}\left(\mathrm{SCH}_{2} \mathrm{CH}\left(\mathrm{N}^{+} \mathrm{H}_{3}\right)(\mathrm{COOH}) \mathrm{Cl}^{-}\right)_{4}$ (4) and $\mathrm{G}_{1} \mathrm{Si}\left(\mathrm{SCH}_{2} \mathrm{CH}\left(\mathrm{NHCOCH}_{3}\right)(\mathrm{COOH})\right)_{8}$

The NMR data for the carbosilane skeleton in these derivatives have been described previously and did not undergo modification upon peripheral functionalization. ${ }^{29}$ In compounds 1-3 containing N-Acetyl-L-cysteine fragments, ${ }^{1} \mathrm{H}-\mathrm{NMR}$ spectra (figure 2) show two signals for hydrogens of methylene group ( $\mathrm{Ha}$ and $\mathrm{Hb}$ ), attached to the sulfur atom close to chiral center molecule located at $3.06(\mathrm{Ha}, \mathrm{Jac} \approx 8)$ and $2.86(\mathrm{Hb}, \mathrm{Jab} \approx 14) \mathrm{ppm}$, while the proton bonded to the chiral center appears as a doublet of doublets at $4.60 \mathrm{ppm}(\mathrm{Hc}, \mathrm{Jac} \approx 8 \mathrm{~Hz}$ and $\mathrm{Jbc} \approx 5 \mathrm{~Hz}$ ). The methyl group of the acetyl fragment is observed at $2.01 \mathrm{ppm}$ (figure 2). In the case of cysteine derivatives (figure 3), the methylene group ( $\mathrm{Ha}$ and $\mathrm{Hb}$ ), attached to the sulfur atom appears at $3.07(\mathrm{Ha})$ and $3.01(\mathrm{Hb}) \mathrm{ppm}$ while the proton bonded to the chiral center is located at $4.15 \mathrm{ppm}$. In ${ }^{13} \mathrm{C}$-NMR spectra, the resonances were assigned on the basis of HMQC, HMBC and COSY experiments, for acetyl cysteine derivatives the carbonyl groups of the fragments $-\mathrm{CO}_{2} \mathrm{H}$ and COMe two resonances at $\delta=175.2$ and $174.5 \mathrm{ppm}$ are observed respectively. Two resonances at $\delta=54.9$ and $30.1 \mathrm{ppm}$ are attributed to chiral carbon $(-\mathrm{CH})$ and methylene group bonded to sulfur atom $-\mathrm{CH}_{2} \mathrm{~S}-$ in that order, and the methyl group of the acetyl fragment -COMe is located at 23.9 ppm. 


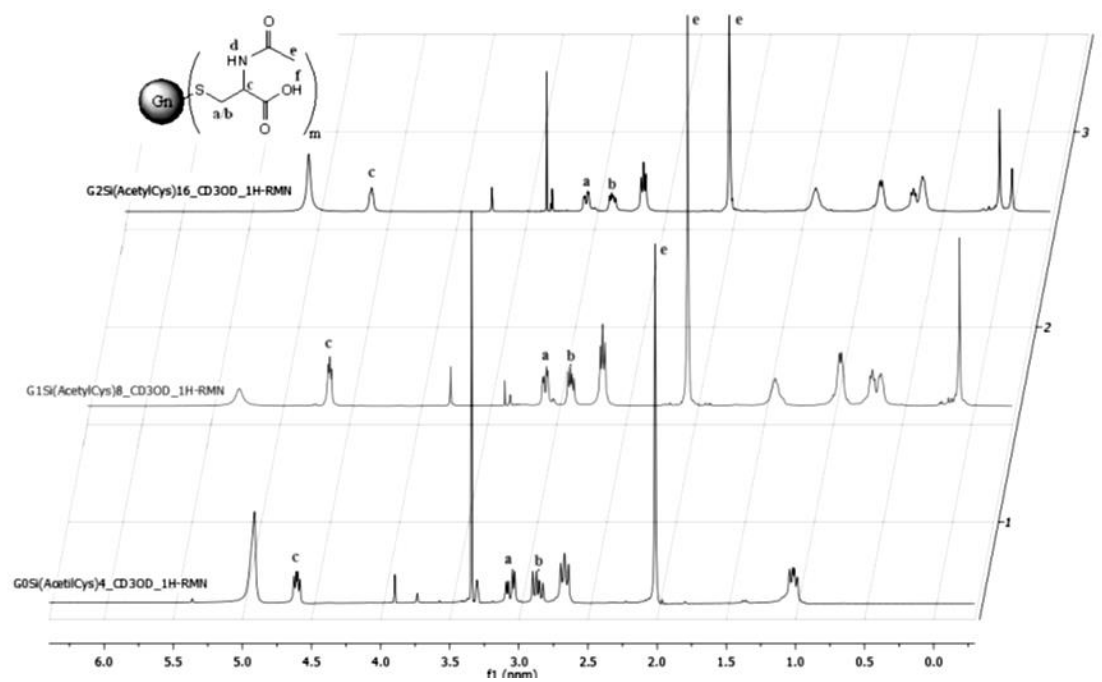

-Figure 2. ${ }^{1} \mathrm{H}-\mathrm{NMR}$ spectrums of dendrimers 1-3 in $\mathrm{CD}_{3} \mathrm{OD}$.-

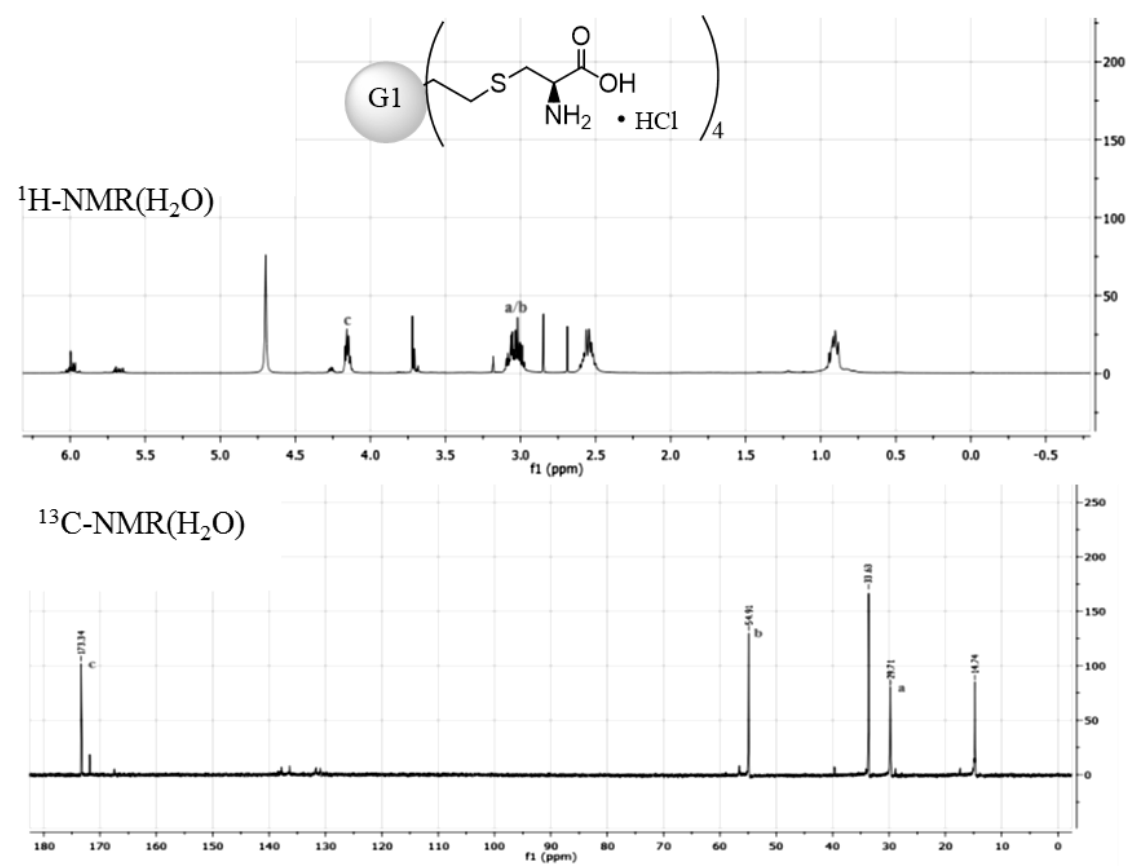

-Figure 3. ${ }^{1} \mathrm{H}$ and ${ }^{13} \mathrm{C}-\mathrm{NMR}$ spectrums of dendrimer 4 in $\mathrm{D}_{2} \mathrm{O}$.

To investigate the ability of chiral carbosilane dendrimers (compounds 1-5) as chiral selectors in $\mathrm{EKC}$, a group of four chiral drugs with different pKa values (razoxane (pKa 2.10), captoprile (pKa 4.02), econazole (pKa 6.77) and clenbuterol (pKa 9.63)) have been used as model compounds. All chiral carbosilane dendrimers at a concentration of $0.01 \%(\mathrm{w} / \mathrm{V})$ in four different buffers $(50 \mathrm{mM}$ formiate $\mathrm{pH} 2.5,50 \mathrm{mM}$ acetate $\mathrm{pH} 5,50 \mathrm{mM}$ bicarbonate $\mathrm{pH} 7$ and $50 \mathrm{mM}$ borate buffer $\mathrm{pH}$ 9) have been checked. All experiments were carried out using a working 
temperature of $20^{\circ} \mathrm{C}$, a separation voltage of $20 \mathrm{kV}$, and a hydrodynamic injection (50 mM during $10 \mathrm{~s}$ ) when solutions of the racemic chiral compounds ( $100 \mathrm{mg} / \mathrm{L}$ of each one) were studies. Of all the experiments performed only in the case of razoxane, a partial chiral discrimination (Rs: 0.9 in an analysis time of 9 min, Table 1) was observed with el dendrimer 2 (dendrimer of $\mathrm{N}$ Acetyl-L-cysteine of first generation) and a $50 \mathrm{mM}$ borate buffer ( $\mathrm{pH} 9$ ).

It is known that the concentration of the chiral selector affect the affinity of the enantiomers for it. ${ }^{30}$ Therefore, the influence of the concentration of dendrimer 2 on the separation of the enantiomers of razoxane was evaluated. Five concentrations of dendrimers $2(0.001,0.005,0.01$, 0.03 and $0.05 \%(\mathrm{w} / \mathrm{V}))$ were tested with a borate buffer at $\mathrm{pH} 9$. An increase in dendrimer concentration resulted in an increase in the analysis time; however, both the increase and the decrease of the dendrimer concentration caused a loss in the chiral resolution obtained with the intermediate concentration of $0.01 \%(\mathrm{w} / \mathrm{v})$ for the razoxane enantiomers. This effect indicates that, as with other chiral selectors used in EKC, such as CDs, there is an optimal concentration for which chiral resolution is highest.

The enantioseparation capacity of dendrimer 2 for the enentiomers of razoxane has been compared with that of other commercial chiral selectors commonly employed in EKC. In this sense, eleven anionics CDs $(\mathrm{CM}-\alpha-\mathrm{CD}, \mathrm{CM}-\beta-\mathrm{CD}, \mathrm{CM}-\gamma-\mathrm{CD}, \mathrm{CE}-\gamma-\mathrm{CD}$, sulfated- $\alpha-\mathrm{CD}$, sulfated- $\beta-C D$, sulfated- $\gamma-C D$, Succ- $\beta-C D$, Succ- $\gamma-C D$, phosphated- $\beta-C D$, sulfobuthylether- $\beta-$ $\mathrm{CD}$ ) all of them at a concentration of $10 \mathrm{mM}$ except sulfobuthylether- $\beta-\mathrm{CD}$ at a concentration of $0.05 \%(\mathrm{w} / \mathrm{V})$ and four bile salts (SC, SDC, STC, STDC) at a concentration of $50 \mathrm{mM}$ were assayed in the same BGE $(50 \mathrm{mM}$ borate buffer $(\mathrm{pH} 9))$ and in the same experimental electrophoretic conditions. Table 1 shows the values of the chiral resolutions and the analysis times, only for those systems for which some type of chiral discrimination has been obtained for the razoxane enantiomers of all the tested ones. As it can be seen, CM- $\alpha-C D, C M-\gamma-C D$, sulfated $\beta-C D$ and sulfobuthylether- $\beta-C D$ provided the partial chiral discrimination towards the enantiomers of razoxane although in all cases the enantioresolution value obtained is same order or less than that obtained with the dendrimer $\mathbf{2}$. Finally, in order to study the possible synergistic effect between chiral selectors, the mixtures between dendrimer $\mathbf{2}$ and the four anionic CD's for which some kind of chiral separation was obtained for the razoxane enantiomers were checked. In all cases the chiral discrimination decreased except for the $0.01 \%(\mathrm{w} / \mathrm{V})$ dendrimer $2-0.05 \%$ $(w / V)$ sulfobutyl ether $\beta$-CD mixture with which similar values were obtained to those obtained with dendrimer 2 alone. 
Table 1. Enantioresolution values (Rs) and analysis times obtained for the enantiomers of razoxane with different $\mathrm{CDs}$ as chiral selectors in the BGE.

\begin{tabular}{c|ccc} 
Chiral selector & Concentration & Rs & Time (min) \\
\hline Dendrimer 2 & $0.01 \%(\mathrm{p} / \mathrm{v})$ & 0.9 & 9.0 \\
$C M-\alpha-C D$ & $10 \mathrm{mM}$ & 0.8 & 6.5 \\
$C M \gamma-C D$ & $10 \mathrm{mM}$ & 0.7 & 6.2 \\
Sulphated $\beta-C D$ & $10 \mathrm{mM}$ & 0.7 & 6.2 \\
Sulfobutylether- $\beta-C D$ & $0.5 \%(\mathrm{p} / \mathrm{v})$ & 0.6 & 5.2
\end{tabular}

\section{CONCLUSION}

This work reports a simple and efficient method for the synthesis of chiral carbosilane dendrimers functionalized with acetyl cysteine and cysteine groups through thiol-ene addition reactions. The presence of multiple chiral groups on these derivatives allows thinking about their possible use as chiral selectors in EKC. First generation dendrimer 2 containing 4 terminals N-Acetyl-Lcysteine groups showed enantioselectivity and separation efficiency to partially resolve a racemic mixture of razoxane. The successful outcome of this preliminary study encourage us to continue with this research line and to explore these new chiral dendrimers as chiral selectors in EKC for a broader range of chiral analytes.

\section{EXPERIMENTAL}

\subsection{General}

All reagents were of analytical grade. L-Cysteine hydrochloride and N-acetyl-L-cysteine were purchased from Sigma Aldrich .Dimethyl formamide (DMF) and $\mathrm{MeOH}$ were purchased from Merck (Darmstadt, Germany). Boric acid, ammonium bicarbonate, razoxane, econazole, clembuterol, sodium taurocholate (STC), sodium taurodeoxycholate (STDC), and sodium hydroxide were purchased from Sigma (St. Louis, MO, USA). Formic acid and acetic acid were from Scharlab (Barcelona, Spain). The employed water was of Milli-Q quality (Millipore, Bedford, MA, USA). Sodium deoxycholate (SDC), sodium cholate (SC), carboxymethylated- $\beta$ CD (CM- $\beta-C D)$ (DS 3), and sulfated- $\beta-C D$ (DS 7-11) were purchased from Fluka (Buchs, Switzerland). Succinyl- $\beta-C D$ (Succ- $\beta-C D)$ (DS 3.5), carboxymethylated- $\gamma-C D$ (CM- $\gamma-C D)$ (DS 3), carboxyethylated- $\gamma-\mathrm{CD} \quad(\mathrm{CE}-\gamma-\mathrm{CD}), \quad$ succinyl- $\gamma-\mathrm{CD} \quad($ Succ- $\gamma-\mathrm{CD}) \quad$ (DS 3.5), carboxymethylated- $\alpha-\mathrm{CD}$ (CM- $\alpha-\mathrm{CD})$ (DS 3.5), phosphated- $\beta-\mathrm{CD}$ (DS 2-6), sulfated- $\alpha-\mathrm{CD}$ (DS 11) and sulfated- $\gamma$-CD (DS 14) were from Cyclolab (Budapest, Hungary). Sulfobuthylether- $\beta-C D$ was from Cydex Pharmaceuthycal (Kansas, USA). The carbosilane 
dendrimers $\mathrm{GnSiVm}$ of different generations were prepared according to reported methods. ${ }^{31}$ Thiol-ene reactions were carried out employing a HPK $125 \mathrm{~W}$ mercury lamp from Heraeus Noblelight with maximum energy at $365 \mathrm{~nm}$, in normal glassware under an inert atmosphere. NMR spectra were recorded on a Varian Unity VXR-300 $\left(300.13\left({ }^{1} \mathrm{H}\right), 75.47 \mathrm{MHz}\left({ }^{13} \mathrm{C}\right)\right)$ or on a Bruker AV400 instrument (400.13 (1H) and 100.60 (13C)). Chemical shifts $(\delta)$ are given in ppm. ${ }^{1} \mathrm{H}$ and ${ }^{13} \mathrm{C}$ resonances were measured relative to solvent peaks considering TMS at $0 \mathrm{ppm}$. When necessary, assignment of resonances was done from HSQC, HMBC, COSY NMR experiments. Elemental analyses were performed on a LECO CHNS-932 instrument. Electrophoretic experiments were carried out in an $\mathrm{HP}^{3 \mathrm{D}} \mathrm{CE}$ system from Agilent Technologies (Palo Alto, CA, USA) with a diode array detector (DAD). The electrophoretic system was controlled with the HP ${ }^{3 \mathrm{D}} \mathrm{CE}$ ChemStation software that included the data collection and analysis. Separations were performed in uncoated fused-silica capillaries of $50 \mu \mathrm{m}$ I.D. and a total length of $58.5 \mathrm{~cm}(50 \mathrm{~cm}$ effective length) from Polymicro Technologies (Phoenix, AZ, USA). pH measurements were performed in a $\mathrm{pH}$-meter model 744 from Metrohm (Herisau, Switzerland). Degassing took place in an ultrasonic bath Ultrasons-H from J.P. Selecta (Barcelona, Spain).

\subsection{Synthesis of $\mathrm{G}_{0} \mathrm{Si}\left(\mathrm{SCH}_{2} \mathrm{CH}\left(\mathrm{NHCOCH}_{3}\right)(\mathrm{COOH})\right)_{4}(1)$}

Two solutions of $\mathrm{G}_{0} \mathrm{SiV}_{4}(0.150 \mathrm{~g}, 1.1 \mathrm{mmol})$ and N-Acetyl-L-cysteine (0.809 g, $\left.4.69 \mathrm{mmol}\right)$ ) in methanol were combined and $5 \mathrm{~mol} \%$ of DMPA $(0.056 \mathrm{~g}, 0.27 \mathrm{mmol})$ was added. The reaction mixture was deoxygenated, and irradiated for $3 \mathrm{~h}$. Another $5 \mathrm{~mol} \%$ of DMPA was added and the reaction mixture was irradiated during $3 \mathrm{~h}$ and monitored by ${ }^{1} \mathrm{H}$ NMR. Then, volatiles were removed under vacuum and the residue was purified by size exclusion chromatography (a polystyrene stationary phase (Bio. Beads SX-1 by Bio-Rad)) in THF to afford compound $\mathbf{1}$ as a pale yellow solid $(0.27 \mathrm{~g}, 31 \%)$.

${ }^{1} \mathrm{H}-\mathrm{NMR}\left(\mathrm{CD}_{3} \mathrm{OD}\right): \delta(\mathrm{ppm}) 4.60\left(\mathrm{dd}, 4 \mathrm{H}, \mathrm{J}_{\mathrm{AC}} \approx 8 \mathrm{~Hz}, \mathrm{~J}_{\mathrm{BC}} \approx 5 \mathrm{~Hz}, \mathrm{SCH}_{2} \mathrm{C} H \mathrm{NH}\right), 3.06(\mathrm{dd}, 4 \mathrm{H}$, $\left.\mathrm{J}_{\mathrm{AC}} \approx 8 \mathrm{~Hz}, \mathrm{~J}_{\mathrm{BA}} \approx 14 \mathrm{~Hz}, \mathrm{SC}\left(H_{A}\right) \mathrm{HCHNH}\right), 2.86\left(\mathrm{dd}, 4 \mathrm{H}, \mathrm{J}_{\mathrm{BC}} \approx 5 \mathrm{~Hz} \mathrm{~J}_{\mathrm{BA}} \approx 14 \mathrm{~Hz}, \mathrm{SC}\left(H_{B}\right) \mathrm{HCHNH}\right), 2.67$ (t, 8H, $\mathrm{SiCH}_{2} \mathrm{CH}_{2} \mathrm{~S}$ ), 2.01 (s, 12H, NHCOCH$\left.H_{3}\right), 1.01$ (t, 8H, $\left.\mathrm{SiCH}_{2} \mathrm{CH}_{2} \mathrm{~S}\right) .{ }^{13} \mathrm{C}-\mathrm{NMR}\left(\mathrm{CD}_{3} \mathrm{OD}\right)$ :

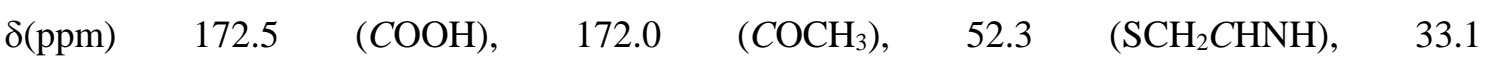
( $\left.\mathrm{SCH}_{2} \mathrm{CHNH}\right), 27.2\left(\mathrm{H}, \mathrm{SiCH}_{2} \mathrm{CH}_{2} \mathrm{~S}\right), 21.4\left(\mathrm{COCH}_{3}\right), 12.6\left(\mathrm{SiCH}_{2} \mathrm{CH}_{2} \mathrm{~S}\right)$. Elemental analysis (\%): calc.: C 42.62, H 6.13, N 7.10; found: C 42.17 H 6.75, N 6.67.

\subsection{Synthesis of $\mathrm{G}_{1} \mathrm{Si}\left(\mathrm{SCH}_{2} \mathrm{CH}\left(\mathrm{NHCOCH}_{3}\right)(\mathrm{COOH})\right)_{8}(2)$}

Compound $\mathbf{2}$ was obtained following a similar procedure to that described for compound $\mathbf{1}$, starting with $\mathrm{G}_{1} \mathrm{SiV}_{8}(0.140 \mathrm{~g}, 0.28 \mathrm{mmol})$, N-Acetyl-L-cysteine (0.383 g, $\left.\left.2.3 \mathrm{mmol}\right)\right)$ and DMPA (0.054 g, $0.23 \mathrm{mmol})$. Dendrimer 2 was obtained as a pale yellow solid $(0.28 \mathrm{~g}, 54 \%)$. 
${ }^{1} \mathrm{H}-\mathrm{NMR}\left(\mathrm{CD}_{3} \mathrm{OD}\right): \delta(\mathrm{ppm}) 4.65\left(\mathrm{dd}, 8 \mathrm{H}, \mathrm{J}_{\mathrm{AC}} \approx 8 \mathrm{~Hz}, \mathrm{~J}_{\mathrm{BC}} \approx 5 \mathrm{~Hz}, \mathrm{SCH}_{2} \mathrm{CHNH}\right), 3.10(\mathrm{dd}, 8 \mathrm{H}$, $\left.\mathrm{J}_{\mathrm{AC}} \approx 8 \mathrm{~Hz}, \mathrm{~J}_{\mathrm{BA}} \approx 14 \mathrm{~Hz}, \mathrm{SC}\left(H_{A}\right) \mathrm{HCHNH}\right), 2.88\left(\mathrm{dd}, 8 \mathrm{H}, \mathrm{J}_{\mathrm{BC}} \approx 5 \mathrm{~Hz}, \mathrm{~J}_{\mathrm{BA}} \approx 14 \mathrm{~Hz}, \mathrm{SC}\left(H_{B}\right) \mathrm{HCHNH}\right), 2.64$ (t, 16H, $\mathrm{SiCH}_{2} \mathrm{CH}_{2} \mathrm{~S}$ ), 2.05 (s, 24H, $\mathrm{COCH}_{3}$ ), 1.37 (t, 16H, $\left.\mathrm{SiCH}_{2} \mathrm{CH}_{2} \mathrm{~S}\right), 0.95$ (m, 8H, $\mathrm{SiCH}_{2} \mathrm{CH}_{2} \mathrm{CH}_{2} \mathrm{Si}$ ), 0.68 (m, 16H, $\mathrm{SiCH}_{2} \mathrm{CH}_{2} \mathrm{CH}_{2} \mathrm{Si}$ ), 0.09 (s, $\left.12 \mathrm{H}, \mathrm{Si}\left(\mathrm{CH}_{3}\right)_{2}\right){ }^{13} \mathrm{C}-\mathrm{NMR}\left(\mathrm{CD}_{3} \mathrm{OD}\right)$ : $\delta(\mathrm{ppm}) 175.2(\mathrm{COOH}), \quad 174.6\left(\mathrm{COCH}_{3}\right), 54.9\left(\mathrm{SCH}_{2} \mathrm{CHNH}\right), 35.7 \quad\left(\mathrm{SCH}_{2} \mathrm{CHNH}\right), 30.1$ $\left(\mathrm{SiCH}_{2} \mathrm{CH}_{2} \mathrm{~S}\right), 23.9\left(\mathrm{NHCOCH}_{3}\right), 21.1-19.7\left(\mathrm{SiCH}_{2} \mathrm{CH}_{2} \mathrm{CH}_{2} \mathrm{Si}\right), \quad 16.8\left(\mathrm{SiCH}_{2} \mathrm{CH}_{2} \mathrm{~S}\right), \quad-3.38$ $\left(\mathrm{Si}\left(\mathrm{CH}_{3}\right)\right)$. Elemental analysis (\%): calc.: C 45.74, H 7.04, N 5.93; found: C 45.28 H 7.20, N 5.64.

\subsection{Synthesis of $\mathrm{G}_{2} \mathrm{Si}\left(\mathrm{SCH}_{2} \mathrm{CH}\left(\mathrm{NHCOCH}_{3}\right)(\mathrm{COOH})\right)_{16}(3)$}

Compound $\mathbf{3}$ was obtained following a similar procedure to that described for compound $\mathbf{1}$, starting with $\mathrm{G}_{2} \mathrm{SiV}_{16}(0.264 \mathrm{~g}, 0.17 \mathrm{mmol})$, N-Acetyl-L-cysteine (0.445 g, $\left.2.7 \mathrm{mmol}\right)$ ) and DMPA (0.054 g, $0.23 \mathrm{mmol})$. Dendrimer 3 was obtained as a pale yellow solid (0.36 g, 50\%).

${ }^{1} \mathrm{H}-\mathrm{NMR}\left(\mathrm{CD}_{3} \mathrm{OD}\right): \delta(\mathrm{ppm}) 4.62\left(\mathrm{dd}, 16 \mathrm{H}, \mathrm{J}_{\mathrm{AC}} \approx 8 \mathrm{~Hz}, \mathrm{JBC} \approx 5 \mathrm{~Hz}, \mathrm{SCH}_{2} \mathrm{CHNH}\right), 3.06(\mathrm{dd}, 16 \mathrm{H}$, $\left.\mathrm{J}_{\mathrm{AC}} \approx 8 \mathrm{~Hz}, \mathrm{~J}_{\mathrm{BA}} \approx 14 \mathrm{~Hz}, \mathrm{SC}\left(H_{A}\right) \mathrm{HCHNH}\right), 2.87\left(\mathrm{dd}, 16 \mathrm{H}, \mathrm{J}_{\mathrm{BC}} \approx 5 \mathrm{~Hz}, \mathrm{~J}_{\mathrm{BA}} \approx 14 \mathrm{~Hz}, \mathrm{SC}\left(H_{B}\right) \mathrm{HCHNH}\right)$, 2.65 (t, 32H, $\mathrm{SiCH}_{2} \mathrm{CH}_{2} \mathrm{~S}$ ), 2.03 (s, 48H, $\mathrm{COCH}_{3}$ ), 1.40 (t, 32H, $\mathrm{SiCH}_{2} \mathrm{CH}_{2} \mathrm{~S}$ ), 0.93 (m, 24H, $\mathrm{SiCH}_{2} \mathrm{CH}_{2} \mathrm{CH}_{2} \mathrm{Si}$ ), 0.67 (m, 48H, $\left.\mathrm{SiCH}_{2}\right), 0.07$ (s, 36H, $\mathrm{Si}\left(\mathrm{CH}_{3}\right)$ ). ${ }^{13} \mathrm{C}-\mathrm{NMR}\left(\mathrm{CD}_{3} \mathrm{OD}\right): \delta(\mathrm{ppm})$ $173.9(\mathrm{COOH}), 173.2(\mathrm{COCH} 3), 53.6\left(\mathrm{SCH}_{2} \mathrm{CHNH}\right), 34.4\left(\mathrm{SCH}_{2} \mathrm{CHNH}\right), 28.8\left(\mathrm{SiCH}_{2} \mathrm{CH}_{2} \mathrm{~S}\right)$, $22.6\left(\mathrm{NHCOCH}_{3}\right), 20.1-19.0\left(\mathrm{SiCH}_{2} \mathrm{CH}_{2} \mathrm{CH}_{2} \mathrm{Si}\right), 15.58\left(-\mathrm{SiCH}_{2} \mathrm{CH}_{2} \mathrm{~S}-\right),-4.14\left(\mathrm{Si}\left(\mathrm{CH}_{3}\right)\right)$.

\subsection{Synthesis of $\mathrm{G}_{0} \mathrm{Si}\left(\mathrm{SCH}_{2} \mathrm{CH}\left(\mathrm{N}^{+} \mathrm{H}_{3}\right)(\mathrm{COOH}) \mathrm{Cl}^{-}\right)_{4}(4)$}

Compound $\mathbf{4}$ was obtained following a similar procedure to that described for compound $\mathbf{1}$, starting with $\mathrm{G}_{0} \mathrm{SiV}_{4}(0.120 \mathrm{~g}, 0.88 \mathrm{mmol})$, L-Cysteine hydrochloride $\left.(0.55 \mathrm{~g}, 3.52 \mathrm{mmol})\right)$ and DMPA (0.04 g, $0.17 \mathrm{mmol})$. Dendrimer 4 was obtained as pale yellow solid $(0.550 \mathrm{~g}, 82 \%)$.

${ }^{1} \mathrm{H}-\mathrm{NMR}\left(\mathrm{D}_{2} \mathrm{O}\right): \delta(\mathrm{ppm}) 4.15\left(\mathrm{dd}, 4 \mathrm{H},-\mathrm{SCH}_{2} \mathrm{CH}\left(\mathrm{N}^{+} \mathrm{H}_{3}\right), 3.07\left(\mathrm{dd}, 4 \mathrm{H},-\mathrm{SC}\left(H_{\mathrm{A}}\right) \mathrm{HCH}\left(\mathrm{N}^{+} \mathrm{H}_{3}\right), 3.01\right.\right.$ $\left(\mathrm{dd}, 4 \mathrm{H},-\mathrm{SC}\left(\mathrm{H}_{\mathrm{B}}\right) \mathrm{HCH}\left(\mathrm{N}^{+} \mathrm{H}_{3}\right), 2.55\right.$ (t, 8H, $\left.\mathrm{SiCH}_{2} \mathrm{CH}_{2} \mathrm{~S}-\right), 0.91$ (t, 8H, $\left.\mathrm{SiCH}_{2} \mathrm{CH}_{2} \mathrm{~S}-\right) .{ }^{13} \mathrm{C}-\mathrm{NMR}$ $\left(\mathrm{D}_{2} \mathrm{O}\right): \delta(\mathrm{ppm}) 173.3(-\mathrm{COOH}), 54.9\left(-\mathrm{SCH}_{2} \mathrm{CH}\right), 33.6\left(\mathrm{SiCH}_{2} \mathrm{CH}_{2} \mathrm{~S}-\right), 29.7\left(-\mathrm{SCH}_{2} \mathrm{CH}\right), 14.7$ $\left(\mathrm{SiCH}_{2} \mathrm{CH}_{2} \mathrm{~S}-\right)$.

\subsection{Synthesis of $\mathrm{G}_{1} \mathrm{Si}\left(\mathrm{SCH}_{2} \mathrm{CH}\left(\mathrm{N}^{+} \mathrm{H}_{3}\right)(\mathrm{COOH}) \mathrm{Cl}^{-}\right)_{8}(5)$}

Compound $\mathbf{5}$ was obtained following a similar procedure to that described for compound $\mathbf{1}$, starting with $\mathrm{G}_{1} \mathrm{SiV}_{8}(0.150 \mathrm{~g}, 0.25 \mathrm{mmol})$, L-Cysteine hydrochloride $\left.(0.323 \mathrm{~g}, 2.05 \mathrm{mmol})\right)$ and DMPA (0.026 g, $0.10 \mathrm{mmol})$. Dendrimer 4 was obtained as pale yellow solid $(0.550 \mathrm{~g}, 65 \%)$.

${ }^{1} \mathrm{H}-\mathrm{NMR}\left(\mathrm{D}_{2} \mathrm{O}\right): \delta(\mathrm{ppm}) 4.16\left(\mathrm{dd}, 8 \mathrm{H},-\mathrm{SCH}_{2} \mathrm{CH}\left(\mathrm{N}^{+} \mathrm{H}_{3}\right), 3.07\left(\mathrm{dd}, 8 \mathrm{H},-\mathrm{SC}\left(H_{\mathrm{A}}\right) \mathrm{HCH}\left(\mathrm{N}^{+} \mathrm{H}_{3}\right), 3.01\right.\right.$ (dd, $8 \mathrm{H},-\mathrm{SC}\left(H_{\mathrm{B}}\right) \mathrm{HCH}\left(\mathrm{N}^{+} \mathrm{H}_{3}\right), 2.57$ (t, 16H, $\left.\mathrm{SiCH}_{2} \mathrm{CH}_{2} \mathrm{~S}-\right), 1.37$ (t, 16H, $\left.\mathrm{SiCH}_{2} \mathrm{CH}_{2} \mathrm{~S}\right), 0.83$ (m, $8 \mathrm{H}, \mathrm{SiCH}_{2} \mathrm{CH}_{2} \mathrm{CH}_{2} \mathrm{Si}$ ), 0.65 (m, 16H, $\mathrm{SiCH}_{2} \mathrm{CH}_{2} \mathrm{CH}_{2} \mathrm{Si}$ ), 0.09 (s, $\left.12 \mathrm{H}, \mathrm{Si}\left(\mathrm{CH}_{3}\right)_{2}\right) \quad{ }^{13} \mathrm{C}-\mathrm{NMR}$ 
$\left(\mathrm{D}_{2} \mathrm{O}\right): \delta(\mathrm{ppm}) 173.3(-\mathrm{COOH}), 54.9\left(-\mathrm{SCH}_{2} \mathrm{CH}\right), 33.6\left(\mathrm{SiCH}_{2} \mathrm{CH}_{2} \mathrm{~S}-\right), 29.7\left(-\mathrm{SCH}_{2} \mathrm{CH}\right), 21.1-$ $19.7\left(\mathrm{SiCH}_{2} \mathrm{CH}_{2} \mathrm{CH}_{2} \mathrm{Si}\right), 14.7\left(\mathrm{SiCH}_{2} \mathrm{CH}_{2} \mathrm{~S}-\right)$, $-3.38\left(\mathrm{Si}\left(\mathrm{CH}_{3}\right)\right)$.

\subsection{EKC Procedure}

At the beginning of each working day the capillary was flushed with $\mathrm{NaOH} 0.1 \mathrm{M}$ for 10 min, 5 min with Milli-Q water and 40 min with the buffer in basic conditions and with $\mathrm{MeOH}$ for 5 min, $\mathrm{NaOH} 1 \mathrm{M}$ for $25 \mathrm{~min}, 5$ in with Milli-Q water, 5 min with $\mathrm{HCl} 0.1 \mathrm{M}$ and 30 min with the buffer in acid conditions. In order to ensure the repeatability between injections, the capillary was flushed with $\mathrm{NaOH} 0.1 \mathrm{M}$ for $5 \mathrm{~min}, 5$ min with the buffer and 2 min with the BGE in basic or acid conditions. Buffer solutions were prepared by dissolving the appropriate amount of formic acid, acetic acid, ammonium bicarbonate or boric acid in Milli-Q water, adjusting the $\mathrm{pH}$ to the desired value ( $\mathrm{pH} 2.5,5.0,7.0$, or 9.0, respectively) with 0.1 or $1 \mathrm{M} \mathrm{NaOH}$ before completing the volume with water to get the desired buffer concentration. Finally, BGEs were prepared by dissolving the appropriate amount of the chiral selectors in the buffer solution. Stock standard solutions of racemic captopril, econazole and clenbuterol were prepared by dissolving the appropriate amount of these drugs in $\mathrm{MeOH}$ and razoxane was prepared by dissolving the appropriate amount in Milli-Q water $/ 25 \%$ DMF (v/v). These solutions were stored at $4{ }^{\circ} \mathrm{C}$. All solutions (buffers and standards) were filtered through $0.45 \mu \mathrm{m}$ pore size nylon membrane filters before their injection in the CE system.

\section{ACKNOWLEDGEMENTS}

This work was supported by projects CTQ-2014-54004-P and CTQ2013-48740-P (Spanish Ministry of Economy and Competitivity) and project CCG2016/EXP-068 (University of Alcalá). CIBER-BBN as an initiative funded by the VI National R\&D\&i Plan 2008-2011, Iniciativa Ingenio 2010, Consolider Program, CIBER Actions and financed by the Instituto de Salud Carlos III with assistance from the European Regional Development Fund. S.Q. thanks University of Alcalá for a research initiation fellowship. Authors thank N. Menéndez-López and P. Sotillo Cañas for technical assistance.

\section{REFERENCES}

1 Anthonsen, T. Chemmedchem 2012, 7, 534-534.

2 Hardikar, M. S. J Indian Med Assoc 2008, 106, 615-624.

3 Izake, E. L. J Pharm Sci-Us 2007, 96, 1659-1676.

4 Bounoua, N.; Sekkoum, K.; Belboukhari, N.; Cheriti, A.; Aboul-Enein, H. Y. J Liq Chromatogr R T 2016, 39, 513-519. 
Plotka, J. M.; Biziuk, M.; Morrison, C.; Namiesnik, J. Trac-Trend Anal Chem 2014, 56, 74-89.

6 Saz, J. M.; Marina, M. L. J Chromatogr A 2016, 1467, 79-94.

7 Tabani, H.; Mahyari, M.; Sahragard, A.; Fakhari, A. R.; Shaabani, A. 2015, 36, 305-311.

8 Du, Y.; Chen, B. Chim Oggi 2010, 28, 37-42.

9 Hisham, H.; Andre, K.; Thomas, J. Curr Anal Chem 2012, 8, 124-132.

10 Zhang, Q.; Qi, X.; Feng, C.; Tong, S.; Rui, M. J Chromatogr A 2016, 1462, 146-152.

11 He, B.-J.; Yin, C.-Q.; Li, S.-R.; Bai, Z.-W. Chirality 2010, 22, 69-76.

12 Huang, S. H.; Li, S. R.; Bai, Z. W.; Pan, Z. Q.; Yin, C. Q. Chromatographia 2006, 64, 641646.

13 Maria, B.; Barbara, K. Curr Med Chem 2012, 19, 4895-4895.

14 Sepulveda-Crespo, D.; Jiménez, J. L.; Gómez, R.; De La Mata, F. J.; Majano, P. L.; MuñozFernaández, M. A.; Gastaminza, P. Nanomed-Nanotechnol 2017, 13, 49-58.

15 Mencia, G.; del Olmo, N. S.; Munoz-Moreno, L.; Maroto-Díaz, M.; Gómez, R.; Ortega, P.; Carmena, M. J.; de la Mata, F. J. New J Chem 2016, 40, 10488-10497.

16 Heredero-Bermejo, I.; Sanchez-Nieves, J.; Soliveri, J.; Gomez, R.; de la Mata, F. J.; CopaPatino, J. L.; Perez-Serrano, J. Int J Pharm 2016, 509, 1-7.

17 Perisé-Barrios, A. J.; Jiménez, J. L.; Dominguez-Soto, A.; de la Mata, F. J.; Corbi, A. L.; Gómez, R.; Muñoz-Fernández, M. A. J Control Release 2014, 184, 51-57.

18 Arevalo, S.; de Jesús, E.; de la Mata, F. J.; Flores, J. C.; Gómez, R. Organometallics 2001, 20, 2583-2592.

19 Stathakis, C.; Arriaga, E. A.; Dovichi, N. J. J Chromatogr A 1998, 817, 233-238.

20 Gray, A. L.; Hsu, J. T. J Chromatogr A 1998, 824, 119-124.

21 Gao, H. Y.; Carlson, J.; Stalcup, A. M.; Heineman, W. R. J Chromatogr Sci 1998, 36, 146154.

22 Thirunarayanan, A.; Raja, S.; Mohanraj, G.; Rajakumar, P. Rsc Adv. 2014, 4, 41778-41783.

23 Petersen, J. F.; Tortzen, C. G.; Pittelkow, M.; Christensen, J. B. Tetrahedron 2015, 71, $1109-1116$.

24 Rajakumar, P.; Raja, R. Tetrahedron Letters 2010, 51, 4365-4370.

25 Shou, C.-Q.; Kang, J.-F.; Song, N.-J. Chinese J Anal Chem 2008, 36, 297-300.

26 van der Made, A. W.; van Leeuwen, P. W. N. M.; de Wilde, J. C.; Brandes, R. A. C. Adv Mater 1993, 5, 466-468.

27 Knapen, J. W. J.; van der Made, A. W.; de Wilde, J. C.; van Leeuwen, P. W. N. M.; Wijkens, P.; Grove, D. M.; van Koten, G. Nature 1994, 372, 659-663.

28 Seyferth, D.; Son, D. Y.; Rheingold, A. L.; Ostrander, R. L. Organometallics 1994, 13, 2682-2690. 
29 Fuentes-Paniagua, E.; Hernández-Ros, J. M.; Sánchez-Milla, M.; Camero, M. A.; Maly, M.; Pérez-Serrano, J.; Copa-Patiño, J. L.; Sánchez-Nieves, J.; Soliveri, J.; Gómez, R.; Javier de la Mata, F. Rsc Adv. 2014, 4, 1256-1265.

30 Marina, M. L.; Castro, A. R.; Ríos, A.; Valcárcel, M.; Cases, M. V. Analysis and Detection by Capillary Electrophoresis; Elsevier, 2005.

31 Fuentes-Paniagua, E.; Peña-González, C. E.; Galán, M.; Gómez, R.; de la Mata, F. J.; Sánchez-Nieves, J. Organometallics 2013, 32, 1789-1796. 